\title{
DESKRIPTIF HYGIENE SANITASI PENGELOLAAN MAKANAN DI LEMBAGA PEMASYARAKATAN KELAS IIB KABUPATEN CILACAP TAHUN 2017
}

\author{
Qorina Nurul Azizah ${ }^{*}$, Agus Subagiyo ${ }^{* *}$ \\ Jurusan Kesehatan Lingkungan, Politeknik Kesehatan Kemenkes Semarang, \\ Jl.Raya Baturaden KM 12 Purwokerto, Indonesia
}

\begin{abstract}
Abstrak
Makanan merupakan suatu hal yang sangat penting dalam kehidupan manusia. Makanan dan minuman yang dipergunakan untuk masyarakat harus didasarkan pada standar dan atau persyaratan kesehatan. Narapidana berhak mendapatkan pelayanan kesehatan \& makanan yang layak maka perlu ada upaya pencegahan penyakit yang salah satunya disebabkan oleh makanan dengan memperhatikan prinsipprinsip hygiene sanitasi makanan di Lapas Kelas IIB Cilacap dengan enam prinsip hygiene sanitasi makanan antara lain pengamanan bahan makanan, penyimpanan bahan makanan, pengolahan makanan, pengangkutan makanan, penyimpanan makanan jadi dan penyajian makanan. Metode penelitian yang peneliti buat yaitu dengan menggunakan metode deskriptif yaitu dengan melakukan observasi dan wawancara. Sedangkan cara pengumpulan yang dilakukan dalam penelitian adalah observasi, wawancara, pemeriksaan kualitas mikrobiologi makanan. Hasil penelitian yang diperoleh dari enam prinsip hygiene sanitasi pengelolaan makanan yaitu, pengamanan bahan makanan sebesar 94,8\%, penyimpanan bahan makanan sebesar $86,66 \%$, pengolahan makanan sebesar 75,85\%, pengangkutan makanan sebesar $84 \%$, penyimpanan makanan jadi sebesar 91,30\%, serta penyajian makanan sebesar 95\%. Berdasarkan hasil penelitian, dapat disimpulkan bahwa pengelolaan makanan di Lapas Kelas IIB Cilacap sudah memenuhi syarat, namun perlu ditingkatkan lagi untuk personal hygiene penjamah makanan untuk tidak merokok pada saat memasak, memakai APD saat memasak (celemek, masker, sepatu kedap air, dan penutup kepala). Saran yang dapat diberikan yaitu dalam pengelolaan makanan hendaknya mengacu pada aspek hygiene sanitasi makanan serta pentingnya memelihara dan memperbaiki sanitasi yang sudah ada untuk menjadi perbaikan.
\end{abstract}

Kata kunci : Hygiene, Sanitasi, Makanan, Kesehatan Lingkungan

\begin{abstract}
Food is a very important thing in human life. Food and beverages used for the people should be based on health standards and / or requirements. prisoner are entitled to receive proper health and food services so there should be disease prevention efforts which one of them is caused by food by observing the principles of food sanitation hygiene in prison Class IIB Cilacap with six principles of food sanitation hygiene such as food security, food storage, Food processing, food transport, food storage and food presentation. Research methods is to use descriptive method by doing observations and interviews. While the way collection is done in research is observation, interview, inspection of microbiological quality of food. The result of the research was obtained from six principles of food sanitation hygiene that is food security $94,8 \%$, food storage $86,66 \%$, food processing $75,85 \%$, food transportation $84 \%$, food storage 91 , 30\%, and food presentation of 95\%. Based on the results of the study, it can be concluded that the management of food in Class IIB Cilacap prison is eligible, but it needs to be improved again for personal hygiene food handlers to not smoke when cooking, usingPersonal Protective Equipment(PPE) when cooking (apron, mask, waterproof shoes, and head cover ). Suggestions that can be given are in food management should refer to hygiene aspects of food sanitation as well as the importance of maintaining and improving existing sanitation to be improved.
\end{abstract}

Keywords: Hygiene, Sanitation, Food, Environmenthal Health 


\section{Pendahuluan}

Makanan merupakan suatu hal yang sangat penting dalam kehidupan manusia, dimana makanan berfungsi memberikan tenaga atau energi panas pada tubuh, membangun jaringan-jaringan tubuh yang baru, pengatur dan pelindung tubuh terhadap penyakit serta sebagai sumber bahan pengganti sel-sel tua yang usang di makan usia. Makanan yang menarik, nikmat, dan tinggi gizinya, tidak akan berarti sama sekali jika tidak aman untuk di konsumsi. Agar masyarakat terhindar dari makanan dan minuman yang dapat membahayakan kesehatan, pemerintah telah menetapkan standar dan persyaratan agar makanan dan minuman layak dan aman di konsumsi oleh masyarakat dalam (Undang-Undang RI, 2009). Makanan dan minuman yang dipergunakan untuk masyarakat harus didasarkan pada standar dan atau persyaratan kesehatan (Depkes RI,2009). Narapidana berhak mendapatkan pelayanan kesehatan \& makanan yang layak (Undang-Undang RI,1995).

Timbulnya penyakit dipengaruhi oleh 3 faktor yaitu bibit penyakit (agent), manusia (host), dan lingkungan (environment). Dengan mengetahui faktor yangmempengaruhi timbulnya penyakit, kita dapat melakukan upaya promotif danpreventif pada titik-titik yang tepat dan dapat memotong alur perjalanan penularan penyakit. Contoh faktor lingkungan yang dapat mempengaruhi timbulnya penyakit adalah tempat pengolahan makanan. John Gordon dan Lericht (Azrul Azwar, 1986,h.8).

Urutan ke tiga dari 10 penyakit terbanyak yang diderita Narapidana, Anak dan Tahanan bulan Juni tahun 2016 adalah infeksi saluran pernafasan , penyakit kulit dan penyakit gangguan saluran pencernaan yang diakibatkan oleh buruknya kesehatan lingkungan di LAPAS, LPKA, Rutan ,Cabang Rutan, antara lain septictank yang meluap karena over kapasitas, sampah yang terbuka dan menyebabkan pencemaran udara, tidak tersedianya akses untuk cuci tangan dengan sabun dan air mengalir serta kualitas kualitas air minum yang tidak teruji kualitasnya secara berkala di Laboratorium berisiko tercemar E.coli atau bakteri berbahaya lainnya (Kemekumham,2016). Laporan bulanan kesakitan/morbiditas terbanyak yang diderita Narapidana, Anak dan Tahanan bulan Desember 2016 Lapas Kelas IIB Kabupaten Cilacap adalah ISPA 12 orang, dermatitis 11 orang dan disentri 4 orang.

Lapas Kelas IIB Kabupaten Cilacap didirikan pada tahun 1887 , pada tahun 1985

\footnotetext{
${ }^{*}$ qorinanur96@gmail.com

**)agusgiyo@yahoo.co.id
}

dengan keputusan Menteri Kehakiman No: M.04.PR.07.03. Tahun 1985 di fungsikan sebagai Rutan Kelas IIB Kabupaten Cilacap pada tanggal
16 April 2003 dengan keputusan Menteri Kehakiman No: M.50.PR.07.03 Tahun 2003 status Rutan di ubah menjadi Lapas Kelas IIB Kabupaten Cilacap. Kondisi bangunan Lembaga Pemasyarakatan Kelas IIB Kabupaten Cilacap dalam keadaan baik. Gambaran infrastruktur : luas tanah Lapas $5.521 \mathrm{~m}^{2}$, perumahan dinas 9 unit , luas bangunan $3.311 \mathrm{~m}^{2}$, sarana fisik : kantor $1758,67 \mathrm{~m}^{2}$, kamar hunian $1164,33 \mathrm{~m}^{2}$, aula $95 \mathrm{~m}^{2}$, dapur $147 \mathrm{~m}^{2}$, bengkel las $90 \mathrm{~m}^{2}$, masjid $229 \mathrm{~m}^{2}$. jumlah pegawai struktural 12 orang, jumlah petugas keamanan 24, jumlah pegawai 52 Data jumlah tahanan dan narapidana tanggal 13 januari 2017 adalah 314 orang dengan kapasitas Lapas 350 orang .

Mengingat pentingnya makanan yang merupakan kebutuhan pokok manusia untuk kelangsungan hidupnya, maka perlu ada upaya pencegahan penyakit yang salah satunya disebabkan oleh makanan. Upaya ini dilakukan diantaranya dengan cara pengawasan penyehatan makanan pada tempat pengolahan makanan Lembaga Pemasyarakatan / Lapas Kelas IIB Kabupaten Cilacap juga tidak luput dari pengawasan tersebut. Oleh karena itu kebersihan makanan sangat diperhatikan. Mengingat bahaya yang dapat ditimbulkan oleh makanan yang terkontaminasi, maka pengotoran makanan harus dicegah dengan pengawasan kebersihan lingkungan, dan dalam pengolahan makanannya harus sesuai dengan syarat kesehatan. Pengelolaan makanan yang dikerjakan oleh penjamah makanan di Lapas

IIB Cilacap masih belum memperhatikan prinsip-prinsip hygiene sanitasi makanan, di antaranya adalah pemotongan daging dilakukan di lantai tempat pencucian bahan makanan tanpa menggunakan alas/ wadah dalam memotong daging ,penjamah makanan tidak memakai sarung tangan, masker dan celemek serta tidak melakukan pengecekan kesehatan serta penjamah makanan yang ada belum mengikuti pelatihan atau kursus penyehatan makanan, padahal pengetahuan seorang penjamah makanan mengenai hygine sanitasi pengelolaan makanan akan sangat mempengaruhi kualitas makanan yang dihasilkan. Atas pertimbangan hal tersebut dan belum pernah diadakan penelitian di Lembaga Pemasyarakatan Kelas IIB Kabupaten Cilacap.

Perbedaan penelitian ini dengan penelitian sebelumnya adalah Perbedaan penelitian ini dengan penelitian sebelumnya adalah penelitian dilakukan di lembaga pemasyarakatan kelas II Cilacap, pemeriksaan angka lempeng total paada 1 porsi sampel makanan.

Tujuan penelitian ini yaitu mengetahui hygiene sanitasi pengelolaan makanan di Lembaga Pemasyarakatan Kelas IIB Kabupaten Cilacap tahun 2017.

\section{Bahan dan Metode}


Jenis penelitian yang di lakukan oleh peneliti adalah penelitian deskriptif yaitu untuk memperoleh gambaran tentang hygiene sanitasi pengelolaan makanan di Lembaga Pemasyarakatan Kelas IIB Kabupaten Cilacap.

Subyek penelitian ini adalah pengelolaan sanitasi makanan di Lembaga Pemasyarakatan Kelas IIB Kabupaten Cilacap meliputi pemilihan bahan makanan, penyimpanan bahan makanan, pengolahan makanan, pengangkutan makanan, penyimpanan makanan jadi, penyajian makanan dan kualitas mikrobiologi pada satu porsi makan (makan pagi, siang, dan sore ).

Analisis data yang digunakan yaitu, setelah data terkumpul secara keseluruhan, data dapat disajikan dalam bentuk tabel, bagan dan narasi yaitu membandingkan dengan teori yang relevan tentang hygiene sanitasi makanan dan peraturan yang berlaku.

\section{Hasil dan Pembahasan}

a. Kondisi Pengamanan Bahan Makanan

Hasil observasi menunjukkan bahwa pengamanan bahan makanan di Lapas Kelas IIB Cilacap siudah memenuhi syarat dengan prosentase 94,28\%, dengan rincian sebagai berikut :

1) Keadaan Bahan Makanan

Hasil observasi keadaan bahan makanan yang di lakukan oleh peneliti kondisinya memenuhi syarat prosentase 95,65\%, daging dalam keadaan baik yaitu warna cerah/tidak pucat dan mengkilap, tidak berbau busuk dan berlendir. Telur tidak retak/pecah, bersih dan kuat,tidak berbau busuk, telur dalam keadaan kering. Sayuran sayuran tidak banyak berlubang, daun segar/tidak layu, daun belum menguning. Buah-buahan keadaan fisik baik,kulit utuh tidak rusak atau kotor. Warna sesuai dengan warna buah buah yang bersangkutan. Tidak berbau busuk/bau tidak segar. Tidak ada cairan lain selain getah aslinya. Biji-bijian : biji utuh, kering, isinya penuh. Permukaan biji tidak ada noda, jamur atau kotoran lainnya. Biji tidak berlubang. Tidak ada bau lain selain bau khas biji yang bersangkutan. Tidak tumbuh kecambah. Bahan tambahan : Kemasan baik dan berlabel, Terdaftar di Badan Pengawas Obat Dan Makanan. Air : Jumlah air mencukupi, Tidak berbau ,berwarna dan berasa. Kondisi bahan makanan di Lapas Kelas IIB Cilacap sudah memenuhi syarat sesuai peraturan menurut Kemenkes RI No 1096 tahun 2011 tentang Hygiene Sanitasi Jasa Boga.

2) Personal Hygiene Penjamah Makanan

Hasil observasi personal hygine penjamah makanan yang di lakukan oleh peneliti kondisinya memenuhi syarat prosentase 94,28\%. Penjamah makanan tidak berkuku panjang, tidak makan/ mengunyah, Tidak memakai cincin. Tidak merokok selama bekerja. Tidak melakukan kebiasaan meludah, menggaruk-garuk. Menutup mulut saat batuk atau bersin. Selalu mencuci tanggan sebelum dan sesudah bekerja. Tidak menyisir rambut di dekat makanan yang akan dan telah di masak.Personal hygiene penjamah makanan di Lapas Kelas IIB Cilacap sudah baik sudah sesuai peraturan menurut Kemenkes RI No 1096 tahun 2011 tentang Hygiene Sanitasi Jasa Boga.

b. Kondisi Penyimpanan Bahan Makanan

Hasil observasi menunjukkan bahwa penyimpanan bahan makanan di Lapas Kelas IIB Cilacap sudah memenuhi syarat dengan prosentase 86,66\%, dengan rincian sebagai berikut:

1) Perilaku Penyimpanan Bahan Makanan

Hasil observasi perilaku penyimpanan bahan makanan yang di lakukan oleh peneliti kondisinya memenuhi syarat prosentase $75 \%$ Penempatannya terpisah dengan makanan jadi. Penyimpanan dibedakan antara bahan makanan kering dan basah. Tempat penyimpanan bahan makanan rapat serangga dan tikus. Perilaku penyimpanan bahan makanan di Lapas Kelas IIB Cilacap sudah baik sudah sesuai peraturan menurut Kemenkes RI No 1096 tahun 2011 tentang Hygiene Sanitasi Jasa Boga.

2) Sanitasi Tempat Penyimpanan Makanan

Hasil observasi perilaku penyimpanan bahan makanan yang di lakukan oleh peneliti kondisinya memenuhi syarat prosentase $100 \%$. Lantai bersih dan kedap air, dinding bersih, atap tidak bocor, Ventilasi cukup/20\% dari luas lantai. Penerangan tidak menyilaukan. Pintu terbuat dari bahan yang kuat. Bebas dari serangga dan tikus. Sanitasi tempat penyimpanan bahan makanan di Lapas Kelas IIB Cilacap sudah baik sudah sesuai peraturan menurut Kemenkes RI No 1096 tahun 2011 tentang Hygiene Sanitasi Jasa Boga.

3) Pengaturan Tempat Penyimpanan Bahan Makanan

Hasil observasi perilaku penyimpanan bahan makanan yang di lakukan oleh peneliti kondisinya memenuhi syarat prosentase $75 \%$. diantaranya : barang yang di simpan mudah di ambil. Ada rotasi antara barang yang lama dan yang baru. Jarak penyimpanan barang paling atas dengan langit langit minimal $50 \mathrm{~cm}$. Pengaturan tempat penyimpanan tempat penyimpanan bahan makanan di Lapas Kelas IIB Cilacap sudah baik sudah sesuai peraturan menurut Kemenkes RI No 1096 tahun 2011 tentang Hygiene Sanitasi Jasa Boga.

c. Kondisi Pengolahan Makanan

Hasil observasi menunjukkan bahwa pengolahan makanan di Lapas Kelas IIB Cilacap sudah memenuhi syarat dengan prosentase 75,85\%, dengan rincian sebagai berikut:

1) Syarat Penjamah Makanan

Hasil observasi syarat penjamah makanan yang di lakukan oleh peneliti kondisinya memenuhi syarat prosentase $75 \%$. penjamah makanan tidak mengidap penyakit menular seperti typus, kolera, TBC, hepatitis dll karena setiap tahanan yang baru masuk dilakukan pemeriksaan kesehatan, melakukan pengobatan kepada warga binaan yang 
sakit. Perlindungan kontak langsung dengan makanan dilakukan dengan menggunakan penjepit makanan dan sendok. Personal hygiene penjamah makanan tidak berkuku panjang, tidak makan/ mengunyah selama memasak, tidak memakai cincin, Tidak memakai peralatan dan fasilitas yang bukan untuk keperluannya. Penjamah makanan di Lapas Kelas IIB Cilacap sudah baik sudah sesuai peraturan menurut Kemenkes RI No 1096 tahun 2011 tentang Hygiene Sanitasi Jasa Boga.

\section{2) Sanitasi Dapur}

Hasil observasi sanitasi dapur yang di lakukan oleh peneliti kondisinya memenuhi syarat prosentase $83,87 \%$. Sanitasi dapur: lantai kedap air, rata, tidak retak, dan mudah dibersihkan. Permukaan dinding rata,mudah dibersihkan dan berwarna terang. Atap tidak bocor dan kedap air. Langit-langit kedap air, berwarna rerang, dan mudah dibersihkan. Luas ventilasi 20\% dari luas lantai, bebas serangga dan tikus, cross ventilation dan mudah dibersihkan. Pencahayaan tidak menyilaukan dan tersebar keseluruh ruangan. Pintu dapat tertutup dengan baik dan terbuat dari bahan yang kuat. Pembuangan asap lancar, asap tidak mengganggu masyarakat sekitar. Penyediaan air bersih dari PDAM, air bersih mencukupi, memenuhi syarat secara fisik tidak berbau, tidak berasa, dan tidak berwarna. Di dalam dapur terdapat 1 tempat sampah dan di luar dapur terdapat 1 tempat sampah yang mudah dibersihkan. Saluran limbah sapur tertutup dan dibuang ke sungai. Tersedia apar di dalam dapur dan di luar gudang beras. Penjamah makanan di Lapas Kelas IIB Cilacap sudah baik sudah sesuai peraturan menurut Kemenkes RI No 1096 tahun 2011 tentang Hygiene Sanitasi Jasa Boga.

3) Cara Pengolahan Makanan

Hasil observasi cara pengolahan makanan yang di lakukan oleh peneliti kondisinya memenuhi syarat prosentase $100 \%$. Bahan makanan sebelum diolah di cuci bersih. Memasak makanan sesuai dengan tingkat kematangan. Cara pengolahan makanan di Lapas Kelas IIB Cilacap sudah baik sudah sesuai peraturan menurut Kemenkes RI No 1096 tahun 2011 tentang Hygiene Sanitasi Jasa Boga.

4) Pengendalian Serangga dan Vektor di Daapur

Hasil observasi pengendalian serangga dan vektor di dapur yang di lakukan oleh peneliti kondisinya memenuhi syarat prosentase $100 \%$. Pengendalian serangga dan binatang pengganggu:saluran limbah dapur tertutup, memasang kawat kasa untuk mencegah serangga masuk ke dapur, pintu dapur dapat tertutup rapat untuk mencegah tikus dan kecoa masuk ke dapur. Jarak rak bahan dari lantai $15 \mathrm{~cm}$, jarak rak bahan makanan dengan dinding $5 \mathrm{~cm}$ dan jarak rak bahan makanan dengan langit-langit $60 \mathrm{~cm}$. penjamah makanan sebelum memasak cuci tangan terlebih dahulu. Sebelum dan setelah digunakan dapur di bersihkan. Pengendalian serangga dan vektor di Dapur di Lapas Kelas IIB Cilacap sudah baik sudah sesuai peraturan menurut Kemenkes RI No 1096 tahun 2011 tentang Hygiene Sanitasi Jasa Boga.

d. Pengangkutan Makanan

Berdasarkan hasil observasi menunjukkan bahwa pengangkutan makanan di Lapas Kelas IIB Cilacap sudah baik dengan prosentase $84 \%$, dengan rincian sebagai berikut :

1)Personal Hygiene Penjamah Makanan

Hasil observasi personal hygine penjamah makanan yang di lakukan oleh peneliti kondisinya memenuhi syarat prosentase 90\%. Personal hygiene penjamah makanan pada saat pengangkutan makanan : tidak berkuku panjang, tidak makan delama bekerja, tidak memakai cincin, tidak memakai peralatan dan fasilitas yang bukan untuk keperluannya, tidak meludah dan menggaruk-garuk, menutup mulut saat batuk dan bersin, cucitangan sebelum dan sesudah bekerja, tidak menyisir rambut didekat makanan. Personal hygiene penjamah makanan pada saat pengangkutan makanan di Lapas Kelas IIB Cilacap sudah baik sudah sesuai peraturan menurut Kemenkes RI No 1096 tahun 2011 tentang Hygiene Sanitasi Jasa Boga.

2)Tempat/Alat Pengangkut

Hasil observasi alat pengangkut makanan yang di lakukan oleh peneliti kondisinya memenuhi syarat prosentase $100 \%$. Alat pengangkut dalam keadaan bersih, alat pengangkut tertutup, sebelum dan sesudah digunakan dibersihkan. Alat pengangkut dalam keadaan bersih, alat pengangkut tertutup, sebelum dan sesudah digunakan dibersihkan. Alat pengangkut makanan di Lapas Kelas IIB Cilacap sudah baik sudah sesuai peraturan menurut Kemenkes RI No 1096 tahun 2011 tentang Hygiene Sanitasi Jasa Boga.

3) Peralatan

Hasil observasi peralatan yang di lakukan oleh peneliti kondisinya memenuhi syarat prosentase $100 \%$. Bahan peralatan memasak kedap air, bahan anti karat, permukaan halus, mudah dibersihkan, tidak mudah berubah warna, tidak mudah rusak, mudah dibersihkan, mudah mengering jika di cuci. Jalur pengangkutan dekat, tidak terjadi pengotoran selama di angkut,makanan di tempatkan pada wadah yang tertutup. Peralatan di Lapas Kelas IIB Cilacap sudah baik sudah sesuai peraturan menurut Kemenkes RI No 1096 tahun 2011 tentang Hygiene Sanitasi Jasa Boga.

4)Teknik Pengangkutan

Hasil observasi teknik pengangkutan yang di lakukan oleh peneliti kondisinya memenuhi syarat prosentase $100 \%$. Jalur pengangkutan dekat. Pengangkutan tidak melewati sumber pencemar. Makanan ditempatkan pada wadah yang tertutup.Tidak terjadi pengotoran selama diangkut. Teknik pengangkutan makanan di Lapas Kelas IIB 
Cilacap sudah memenuhi syarat sesuai peraturan menurut Kemenkes RI No 1096 tahun 2011 tentang Hygiene Sanitasi Jasa Boga.

e. Penyimpanan Makanan Jadi

Berdasarkan hasil observasi menunjukkan bahwa pengangkutan makanan di Lapas Kelas IIB Cilacap sudah memenuhi syarat dengan prosentase $91,30 \%$ dengan rincian sebagai berikut:

1) Personal Hygiene Penjamah Makanan

Hasil observasi personal hygiene penjamah makanan yang di lakukan oleh peneliti kondisinya memenuhi syarat prosentase $80 \%$. Personal hygiene penjamah makanan pada saat penyimpanan makanan jadi : tidak berkuku panjang, tidak makan delama bekerja, tidak memakai cincin, tidak memakai peralatan dan fasilitas yang bukan untuk keperluannya, tidak meludah dan menggarukgaruk, menutup mulut saat batuk dan bersin, cucitangan sebelum dan sesudah bekerja, tidak menyisir rambut didekat makanan. Personal hygiene penjamah makanan di Lapas Kelas IIB Cilacap sudah memenuhi syarat sesuai peraturan menurut Kemenkes RI No 1096 tahun 2011 tentang Hygiene Sanitasi Jasa Boga.

2) Alat Penyajian Makanan

Hasil observasi alat penyajian makanan yang di lakukan oleh peneliti kondisinya memenuhi syarat prosentase $100 \%$. Alat penyajian makanan dalam keadaan bersih,tempat makan sebelum dan sesudah digunakan di cuci. Pencucian tempat makan dilakukan oleh setiap warga binaan. Tempat makan terbuat dari bahan yang aman dan tertutup. Alat penyajian makanan di Lapas Kelas IIB Cilacap sudah memenuhi syarat sesuai peraturan menurut Kemenkes RI No 1096 tahun 2011 tentang Hygiene Sanitasi Jasa Boga.

3) Jalur Penyajian Makanan

Hasil observasi jalur penyajian makanan yang di lakukan oleh peneliti kondisinya memenuhi syarat prosentase $100 \%$. Jalur penyajian makanan dekat, tidak terjadi pengotoran / kontaminasi selama di angkut, makanan ditempatkan pada ompreng yang tertutup, makanan langsung disajikan tidak di inapkan. Jalur penyajian makanan di Lapas Kelas IIB Cilacap sudah memenuhi syarat sesuai peraturan menurut Kemenkes RI No 1096 tahun 2011 tentang Hygiene Sanitasi Jasa Boga.

4) Tempat Penyimpanan Makanan

Hasil observasi jalur penyajian makanan yang di lakukan oleh peneliti kondisinya memenuhi syarat prosentase $75 \%$. Lantai kedap air dan mudah dikerjakan, bebas serangga dan tikus, ruangan dibersihkan sebelum dan sesudah digunakan, ditempatkan pada rak. Tempat penyimpanan makanan di Lapas Kelas IIB Cilacap sudah memenuhi syarat sesuai peraturan menurut Kemenkes RI No 1096 tahun 2011 tentang Hygiene Sanitasi Jasa Boga.

f. Penyajian Makanan
Berdasarkan hasil observasi menunjukkan bahwa pengangkutan makanan di Lapas Kelas IIB Cilacap sudah memenuhi syarat dengan prosentase 91\%, dengan rincian sebagai berikut:

1) Personal Hygiene Penjamah Makanan

Hasil observasi personal hygiene penjamah makanan yang di lakukan oleh peneliti kondisinya memenuhi syarat prosentase 90\%. . Personal hygiene penjamah makanan pada saat penyajian makanan jadi : tidak berkuku panjang, tidak makan delama bekerja, tidak memakai cincin, tidak memakai peralatan dan fasilitas yang bukan untuk keperluannya, tidak meludah dan menggarukgaruk, menutup mulut saat batuk dan bersin, cucitangan sebelum dan sesudah bekerja. Personal hygiene penjamah makanan pada saat penyajian makanan di Lapas Kelas IIB Cilacap sudah memenuhi syarat sesuai peraturan menurut Kemenkes RI No 1096 tahun 2011 tentang Hygiene Sanitasi Jasa Boga.

2) Alat Penyajian Makanan

Hasil observasi alat penyajian makanan yang di lakukan oleh peneliti kondisinya memenuhi syarat prosentase $100 \%$. Tempat makanan dalam keadaan bersih, trolly pengangkut makanan tertutup, sesudah digunakan tempat makan di bersihkan oleh masing-masing warga binaan, ompreng terbuat dari bahan yang aman, permukaan alat yang berhubungan langsung dengan makanan dalam keadaan baik. Alat penyajian makanan di Lapas Kelas IIB Cilacap sudah memenuhi syarat sesuai peraturan menurut Kemenkes RI No 1096 tahun 2011 tentang Hygiene Sanitasi Jasa Boga.

3) Jalur Penyajian Makanan

Hasil observasi alat jalur penyajian makanan yang di lakukan oleh peneliti kondisinya memenuhi syarat prosentase $100 \%$. Jalur pengangkutan makanan ke blok tahanan dekat, tigak terjadi pengotoran karena tempat makan dan trolly tertutup, pengangkutan makanan tidak melewati sumber pencemar, makanan langsung disajikan tidak di inapkan. Jaiur penyajian makanan di Lapas Kelas IIB Cilacap sudah memenuhi syarat sesuai peraturan menurut Kemenkes RI No 1096 tahun 2011 tentang Hygiene Sanitasi Jasa Boga.

g. Kualitas Mikrobiologi Sampel Makanan

Hasil pemeriksaan sampel makanan pagi, siang dan sore di Lapas Kelas IIB Cilacap terdapat pada table 4.1 yaitu sebagai berikut :

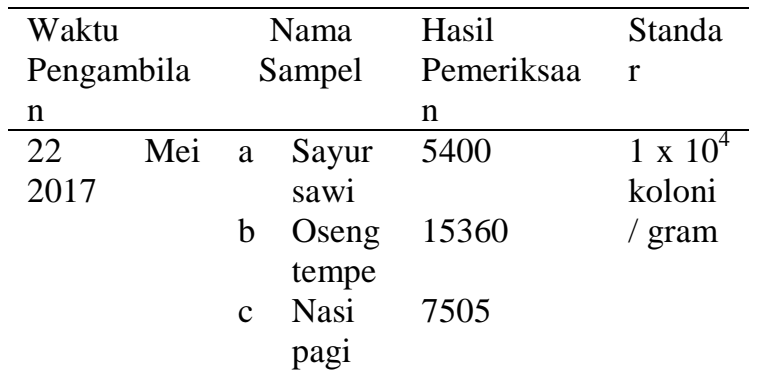




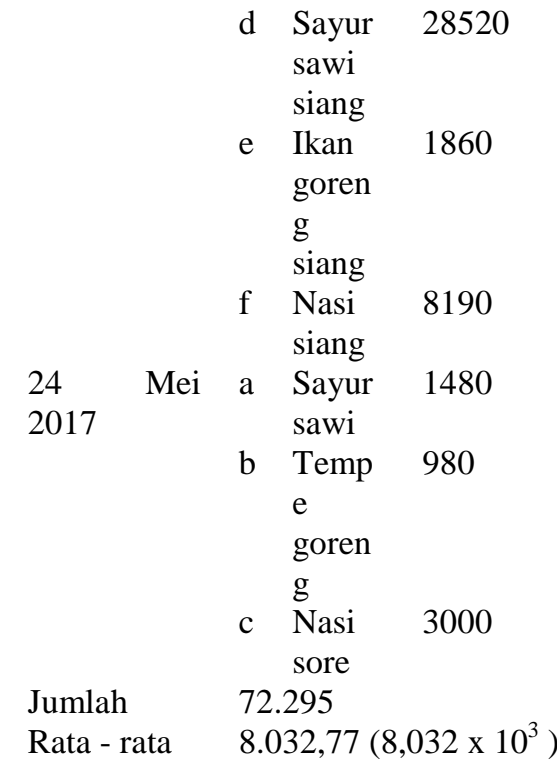

Standar : Peraturan Badan Pengawas Obat dan Makanan RI No. HK. 00.61. 51.4011 tahun 2009 tentang penetapan batas maksimal cemaran mikroba dan kimia dalam makanan.

Pemeriksaan kualitas mikrobiologi dilakukan terhadap sampel makanan yang di analogkan dengan menggunakan jenis makanan lain yang langsung dikonsumsi. Pemeriksaan mikrobiologi hanya terbatas pada Angka Lempeng Total. Berdasarkan pemeriksaan yang dilakukan di Laboratoriun Kesehatan Lingkungan Poltekkes Kemenkes Semarang, hasil pemeriksaannya adalah $8,0 \times 10^{3}$ koloni/g. Berdasarkan Peraturan Badan Pengawas Obat dan Makanan RI. No. HK. 00.06.1.52.4011 tahun 2009 yaitu Angka Lempeng Total menu makanan pagi, siang dan sore adalah 1 x $10^{4} \mathrm{koloni} / \mathrm{g}$, jadi hasil pemeriksaan makanan sampel makanan ini aman untuk dikonsumsi.

\section{Kesimpulan}

Berdasarkan hasil pemeriksaan yang telah dilakukan oleh peneliti dengan cara observasi langsung dengan menggunakan cheklist dan wawancara kepada Kepala Pengelola dapur di Lapas Kelas IIB Cilacap dan penjamah makanan, diperoleh kesimpulan sebagai berikut :

a. Kondisi Pengamanan Bahan Makanan di Lapas Kelas IIB Cilacap sudah memenuhi syarat dengan prosentase 94,28\%.

b. Kondisi Penyimpanan Bahan Makanan di Lapas Kelas IIB Cilacap sudah baik dengan prosentase 86,66\%.

c. Kondisi Pengolahan Makanan di Lapas Kelas IIB Cilacap sudah memenuhi syarat dengan prosentase 75,85\%.

d. Kondisi Pengangkutan Makanan di Lapas Kelas IIB Cilacap sudah memenuhi syarat dengan prosentase $84 \%$.

e. Kondisi Penyimpanan Makanan Jadi di Lapas Kelas IIB Cilacap sudah baik dengan prosentase 91,30 ,\%. f. Kondisi Penyajian Makanan di Lapas Kelas IIB Cilacap sudah memenuhi syarat dengan prosentase 95\%.

g. Kondisi Kualitas Mikrobiologi Angka Lempeng Total pada sampel menu makanan pagi, makan siang dan makan sore di Lapas Kelas IIB Cilacap sudah baik dengan hasil pemeriksaan $8,0 \times 10^{3}$.

3. Daftar Pustaka

Afita Imanika, 2012, Studi Tentang Hygiene Sanitasi Pengelolaan Makanan di RSUD dr. $R$. Goeteng Taroenadibarata Kabupaten Purbalingga, Karya Tulis Ilmiah, Purwokerto: Kementerian Ksehatan RI Politeknik Kesehatan Semarang Jurusan Kesehatan Lingkungan Purwokerto

Azwar Azrul, 1986, Pengantar Ilmu Kesehatan Lingkungan, Jakarta: PT MutiaraSumber Widya

Chasan S Kusnandi. Pengendalian Vektor dan Binatang Pengganggu, Makassar: Institut Penerbitan Jurusan Kesehatan Lingkungan Poltekkes Makassar

Dirjen PPM \& PLP Depkes 1998, Pedoman Pengawan Kualitas Makanan

Dirjen PP \& PL Depkes 2010, Kumpulan Modul Kursus Hygiene Sanitasi Makanan \&Minuman. Jakarta

Dirjen BKM \& BGM Depkes 2009, Pedoman Penyelenggaraan Makanan di Lembaga Pemasyarakatan dan Rumah Tahanan Negara, Jakarta

Dwi Bayu ,dkk, 2015 Penyehatan Makanan Minuman, Purwokrto, Laboratorium Kesehatan Lingkungan

Keputusan Direktur Jendral Pemasyarakatan Kementerian Hukum dan HAM Republik Indonesia Nomor PAS - 498.PK.01.07.02 Tahun 2015 tentang Standar Penyelenggaraan Makanan di Lembaga Pemasyarakatan, Rumah Tahanan Negara dan Cabang Rumah Tahanan Negara

Keputusan Menteri Kesehatan Republik Indonesia Nomor1096/Menkes/PER/VI/ 2011 tentang hygiene sanitai jasaboga

Keputusan Menteri Kesehatan Republik Indonesia Nomor 942/Menkes/SK /VII/2003

Tentang Pedoman Persyaratan Hygiene Sanitasi Makanan

Jajanan

Peraturan Kepala Badan Pengawas Obat dan Makanan Republik Indonesia Nomor HK.00.06.1.52.4011 Tahun 2009 tentang Penetapan Batas Maksimum Cemaran Mikroba dan Kimia dalam Makanan

Reksosoebroto dan Soebagio. 1978. Hygiene dan Sanitasi, Jakarta : Akademi Kesehatan Teknologi Sanitasi

Suharsimi Arikunto, 1998, Prosedur Penelitian, Jakarta : Rineka Cipta 
Surat Edaran Kementerian Hukum dan HAM , Nomor

Pas-373. PK.01.07.01 Tahun 2016 Tentang Sanitasi dan Kesehatan Lingkungan Lapas, LPKA, Rutan dan Cabang Rutan)

Sabarguna, B.S,Dkk, 2010,Sanitasi Makanan dan Minuman Menuju Peningkatan MutuEfisiensi Rumah Sakit,Jakarta: Salemba Medika

Surasri, Siti. 1989. Prinsip Sanitasi Makanan. Jakarta, Pusdiknakes RI

Tri Cahyono, 2014, Pedoman Penulisan Proposal Penelitian Dan Karya Tulis Ilmiah/Skripsi Edisi Revisi Ketiga, Purwokerto: Kementerian Kesehatan Lingkungan Purwokerto
Undang-Undang Republik Indonesia Nomor 12 Tahun 1995 Tentang Pemasyarakatan Undang-Undang Nomor 36 Tahun 2009 tentang kesehatan 